\title{
The Influence of Temperature on Stability of Aluminum Foam Cell Wall during Foaming Process
}

\author{
Dewi Puspitasari ${ }^{1}$, Fatthie Khairullah Hishyam Rabie $^{1}$, Turnad Lenggo Ginta ${ }^{1}$, Jundika \\ Candra Kurnia ${ }^{1}$, and Mazli Mustapha ${ }^{1, *}$ \\ ${ }^{1}$ Mechanical Engineering Department, Universiti Teknologi PETRONAS, Bandar Seri Iskandar, \\ Perak, Malaysia
}

\begin{abstract}
This study concerns about the influence of foaming temperature which is applied to foaming process of aluminum foam to improve the stability of aluminum foam cell wall. Powder metallurgical method with four major foaming temperatures of $750^{\circ} \mathrm{C}, 800^{\circ} \mathrm{C}, 850^{\circ} \mathrm{C}$ and $900^{\circ} \mathrm{C}$ have been selected. Furthermore, the porosity of the foam was determined by ImageJ Analysis Software. Microhardness testing on the cell wall of aluminium foam was conducted according to ASTM E 92 using microhardness tester LM24AT with 200 grams and $15 \mathrm{~s}$ for loading time. The universal testing machine was applied to characterize the effect of foaming temperature on compression strength. The aluminum foam was observed in macroscopic and microscopic level using optical microscope $(\mathrm{OM})$. The result revealed that the foaming temperature of $800^{\circ} \mathrm{C}$ gave the lowest value of porosity, with the highest hardness and compressive strength of $55.29 \mathrm{HV}$ and 1.41 MPa, respectively. In addition, the highest porosity level was acquired by foaming temperature which was set at $900{ }^{\circ} \mathrm{C}$. The lowest hardness value of $38.50 \mathrm{HV}$ was obtained by foaming temperature of $700^{\circ} \mathrm{C}$ and the minimum compressive strength value of $0.75 \mathrm{MPa}$ was exhibited when the foaming temperature was set at $900^{\circ} \mathrm{C}$.
\end{abstract}

\section{Introduction}

The development of automobile industry requires material in low weight, high strength, and high energy absorption to diminish impact forces [1]. To achieve this goal aluminum foam have been developed [2]. Aluminum foam is material that is produced by trapping gas bubbles in the liquid or solid [3], having unique combination of mechanical, physical and acoustic properties [1], such as high stiffness, low specific weight and high strength [4]. Due to the combination of properties, the materials are widely used in structural and functional applications, such as Al-based foams having an excellent potential in the fields of automobile, aerospace, shipment, railway, filtration, fluid flow control, water purification, acoustic control and civil construction [5], [6].

Aluminum foam can be produced by various processing routes. One of the methods that is widely used in production of foam is powder metallurgy (PM) technique [7]. It involves mixing metal powders and a blowing agent, densifying the powder blend to produce a dense 
precursor. Afterwards the foaming process is initiated by heating the dense precursor above its melting temperature [8]. The microstructure changes during foaming process have a significant influence on the quality of the final product [9]. The quality of final structure of the solidified foam depend on foaming temperature during foaming process [10]. According to the Miyoshi et al [11], the stability of the bubble size and the total volume of porosity related to the carbon dioxide gas content in the melted alloy are measured by the growth rate between a bubble and solid interface that is influenced by foaming temperature. Kumar et al [12] investigate the effect of the foaming temperature on polyhedron structure of aluminum foam and they found that the resulting the cell size and porosity was increased with elevated foaming temperature. Furthermore, it is necessary to obtain the optimum foaming temperature during foaming process since the melt flow could impede the rate of cell coarsening. In this study, the closed cell aluminum foam will be produced trough powder metallurgy technique with different combination of foaming temperature during foaming process. The effect of foaming temperature on the stability of aluminum foam during foaming process will be studied to determine the optimum parameter of temperature during foaming process in order to improve the stability of cell wall closed cell aluminum foam.

\section{Methodology}

Aluminum powder ( $>99 \%$ purity, 20$)$ and Titanium hydride $(>99.5 \%$ purity, $<50)$ powders were used as a precursor and blowing agent, respectively. In the powder compaction process, aluminum and titanium hydride were mixed with the ratio of 1:0.3 to produce 100-gram precursor materials. The process is followed by compaction of powder using compaction die with constant force of $450 \mathrm{~N}$, then precursor is ready to be foamed. As mentioned before, there are four major temperatures that will be selected namely $750^{\circ} \mathrm{C}, 800^{\circ} \mathrm{C}, 850^{\circ} \mathrm{C}$ and $900^{\circ} \mathrm{C}$ with constant foaming time of three minutes. The specimens were then undergone furnace cooling process. The aluminum foam was mounted by using hot mounting machine with carbon as a resin for easy of handing. Grinding was carried out with P480, P680 and P1200 abrasive papers. After grinding, polishing process is needed to ensure the sample is mirror finishing stage by using P700 diamond polishing reagent, the specimens were etched using Keller's etchant (distilled water of $190 \mathrm{ml}$, HNO3 of $5 \mathrm{ml}, \mathrm{HCl}$ of $3 \mathrm{ml}$, and $\mathrm{HF}$ of 2 $\mathrm{ml}$ ). The aluminum foams are observed for macroscopic and microscopic level by using optical microscope (OM). Leica Application Suite (LAS V4.5) software was used to analyses the micrographs. The ImageJ Analysis Software was applied to investigate the area of porosity of the aluminum foam. Moreover, from the total area of porosity measurement, the selection of optimum temperature can be determined. Microhardness test on cell wall nodes was conducted according to ASTM E384 using microhardness tester LM247AT. Three hardness readings were taken on each node and the average was calculated. Microhardness value is defined as the ratio between the applied load and the total area of indented that produce the loading of draw pyramid. The Vickers microhardness can be classified using Equation 1[13].

$$
H V=1.8545 X\left(\frac{F}{d^{2}}\right)
$$

where $\mathrm{F}$ was denoted as load force in gram force (gf) and d was average diagonal of mark $(\mu m)$. The compression test specimens were cut in the dimension. Quasi static compression test was conducted by universal testing machine (max load $50 \mathrm{kN}$ ) with computer interface for data acquisition and control. The test was carried out under displacement control with a cross head speed of $1 \mathrm{~mm} \mathrm{~s}-1$ according to standard test method for compressive properties of rigid cellular plastics (ASTM D 1621-00). Compressive strength was determined as the 
upper limit of the elastic region beyond which the cells undergo irreversible deformation or the first peak stress on the stress-strain curve [14].

\section{Result and discussion}

\subsection{Porosity and cell wall behaviour}

Figure 1 shows cross sectional area images of the aluminum foam for measurement purposed. These samples need to be at threshold condition before undergoing analyzing process with the quality of 8 -bit. The samples which was found at $800^{\circ} \mathrm{C}$ and $850^{\circ} \mathrm{C}$ possess uniform porosity ad rigid cell wall structure in Figure $1 \mathrm{~b}$ and $1 \mathrm{c}$. The unstable cell wall structure with high porosity were exhibited by samples which were formed at $750^{\circ} \mathrm{C}$ and $900{ }^{\circ} \mathrm{C}$, respectively as shows in Figure 1a and 1d. The porosity of the samples with different foaming temperature ranging from $750{ }^{\circ} \mathrm{C}$ to $900{ }^{\circ} \mathrm{C}$ using ImageJ analysis software in shown in Figure 2. The area of porosity on macroscopic and microscopic level of each sample are shown on Figure 3. It can be seen that the total area of porosity decrease with the foaming temperature is increased to $800^{\circ} \mathrm{C}$. The amount of porosity however is increased when the foaming temperature is increased from $850^{\circ} \mathrm{C}$ to $900{ }^{\circ} \mathrm{C}$. This behavior suggests that the aluminum has not fully undergone the foaming process at $750^{\circ} \mathrm{C}$. When the aluminum was foamed at $800^{\circ} \mathrm{C}$ and $850^{\circ} \mathrm{C}$ respectively, a uniform porosity was observed. These phenomena are due to the instability in the foaming behavior which decrease the viscosity of the aluminum melt during the elevated foam temperature. Similar observed was also reported by Song et al [15] where the pore morphology develops to a homogeneous particle when foaming temperature rises. Commonly, the pore morphology of $\mathrm{Al}$ foams becomes inhomogeneous with increasing foaming temperature.

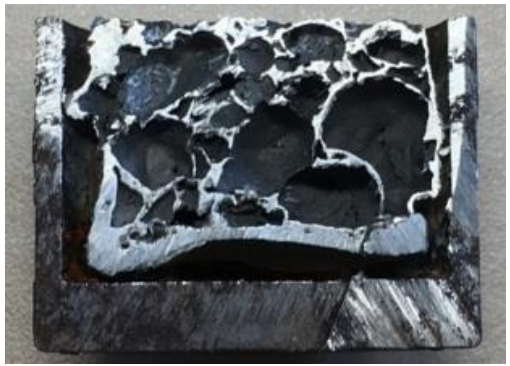

(a)

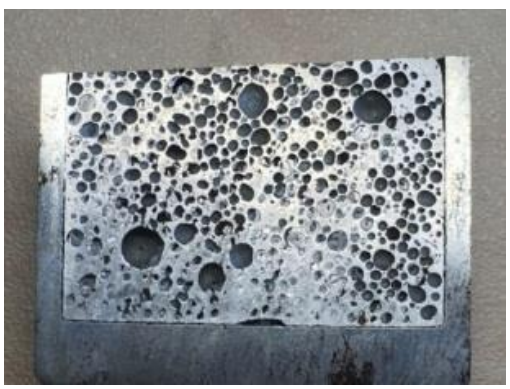

(c)

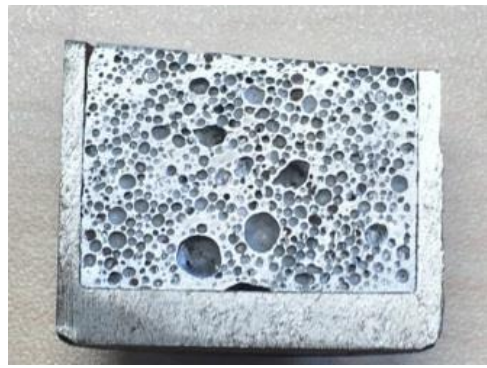

(b)

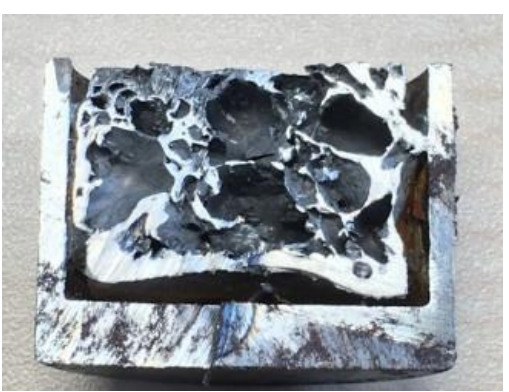

(d)

Fig. 1. Cross Sectional area at foaming aluminum: (a) $750^{\circ} \mathrm{C}$, (b) $800^{\circ} \mathrm{C}$, (c) $850^{\circ} \mathrm{C}$ and (e) $900^{\circ} \mathrm{C}$ 


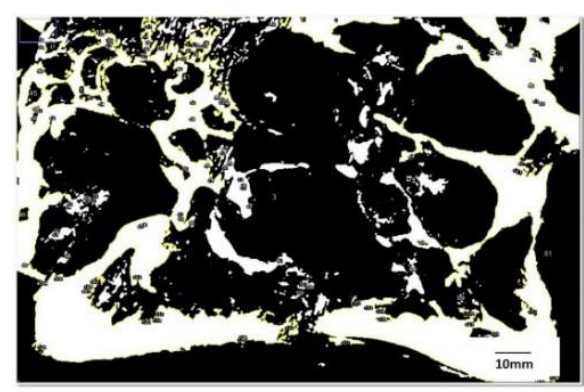

(a)

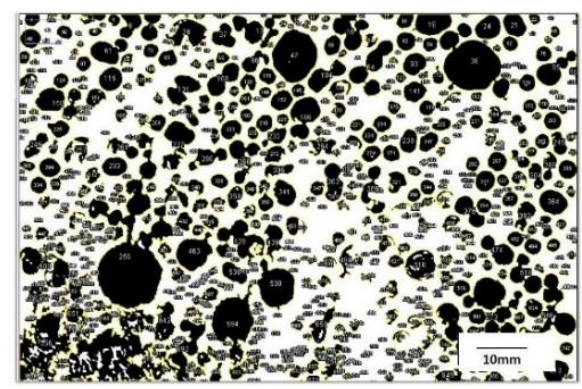

(c)

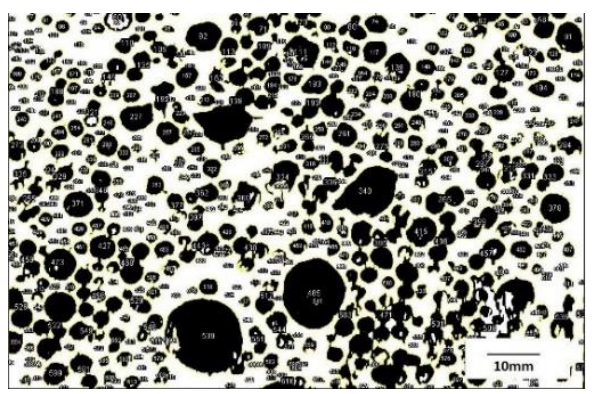

(b)

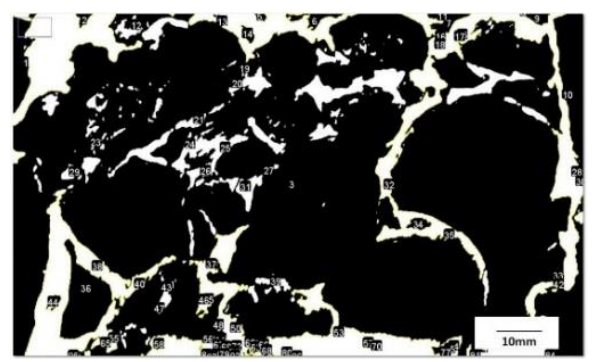

(d)

Fig. 2. Porosity Located on Image J Analysis Software on: (a) $750^{\circ} \mathrm{C}$, (b) $800^{\circ} \mathrm{C}$, (c) $850^{\circ} \mathrm{C}$ and (d) $900^{\circ} \mathrm{C}$

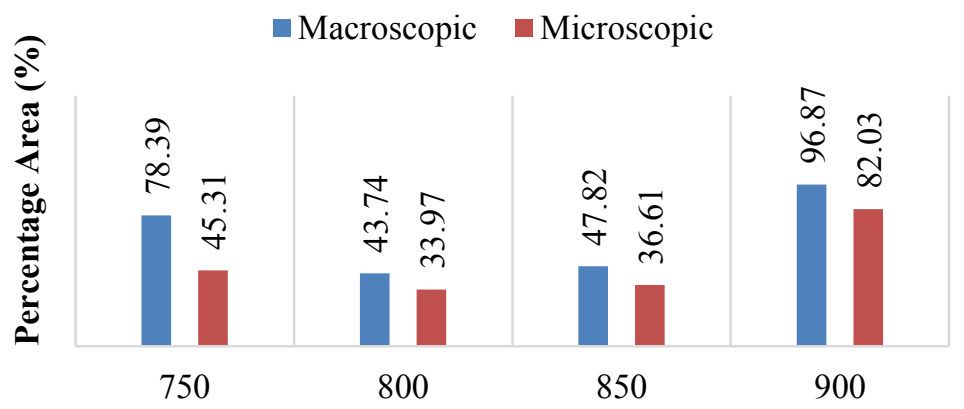

Foaming Temperature $\left({ }^{\circ} \mathrm{C}\right)$

Fig. 3. Porosity on macroscopic and microscopic of each sample

\subsection{Microhardness value of aluminum foam}

Further analysis is conducted with the hardness test by using micro-Vickers hardness with the force of $200 \mathrm{gf}$ (gram force) of load. The graph of hardness value of aluminum foam with different foaming temperature is presented in Figure 4. As shown in the figure, sample 2 shows the highest hardness value of 55.29 HV. This is due to the fact that the samples have uniform porosity and rigid cell wall structure which are attached closer to each other as being observed via macroscopic and microscopic level. Sample 4 shows the lowest hardness value of $38.5 \mathrm{HV}$ due to the presence of highest amount of non-uniformed porosity with detected cell wall structure. 


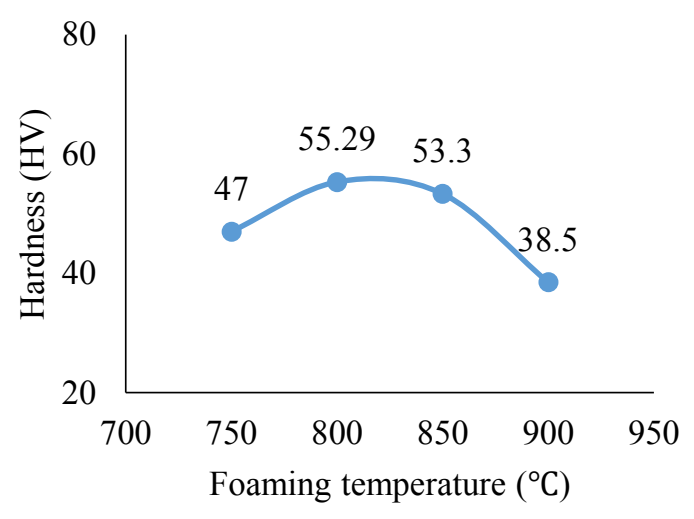

Fig. 4. Microhardness value of aluminum foam with different foaming temperature

\subsection{Compression strength}

Figure 5 shows the compressive stress-strain curves of the aluminum foams with different foaming temperature and the compressive strength values for $750{ }^{\circ} \mathrm{C}, 800^{\circ} \mathrm{C}, 850^{\circ} \mathrm{C}$, and $900^{\circ} \mathrm{C}$ are $1.1 \mathrm{MPa}, 1.41 \mathrm{MPa}, 1.23 \mathrm{MPa}$, and $0.75 \mathrm{MPa}$, respectively. The stress-strain curves were commonly characterized by an initial elastic response, followed by a deformation "plateau" with a positive slop and finally a transition to densification [16]. Throughout the compression testing, the collapse of the closed cell aluminum foam was analyzed through layer by layer, starting at the top propagation until full densification occurs [17]. From the result obtained, it can be found that sample 2 had the highest compression strength value of $1.41 \mathrm{MPa}$ with the shortest deformation of plateau due to the small and uniform pores of the samples. Meanwhile sample 4 has the smallest compressive strength value but greater plateau deformation. This observation it due to the present of large size and no uniform porosity in the samples which made the sample takes longer time to fully flattened during compression. As explained by $\mathrm{Yu}$ et al. [18] explain that the larger diameter of the cell size will produce inhomogeneity of density and the stress drop ratio will develop into larger.

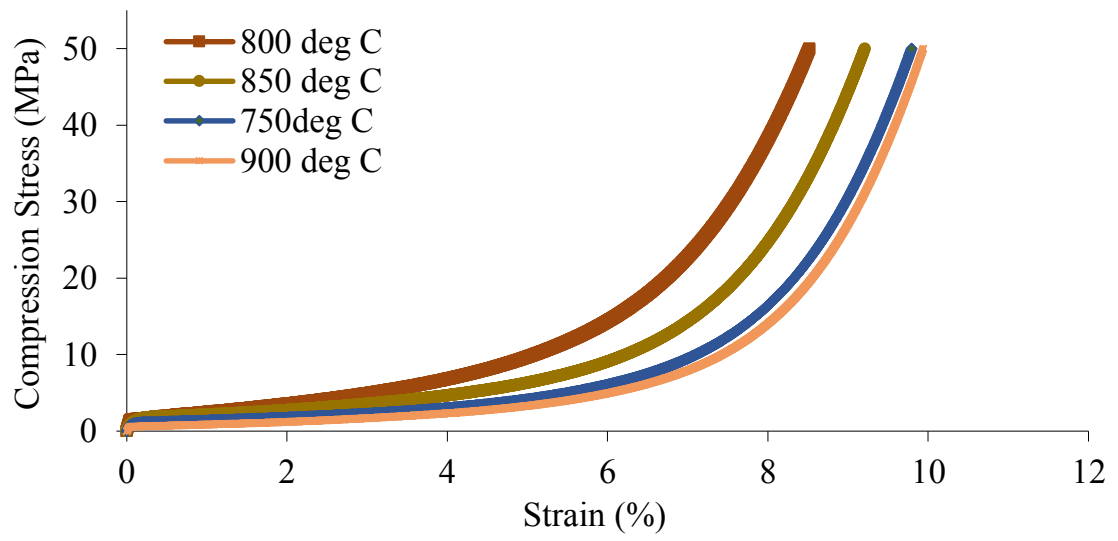

Fig. 5. Stress-strain graph of aluminum foam with different foaming temperature 


\section{Conclusion}

In this current study, the influence of foaming temperature on the properties of cell wall aluminum foam have been investigated. This study shows the optimum temperature for foaming process of aluminum is $800^{\circ} \mathrm{C}$ which were confirmed by macroscopic and microscopic analysis. For the macroscopic and microscopic analysis, the percentage area of the pores is 43.74 and 33.97 respectively. The aluminum that was foamed of $800^{\circ} \mathrm{C}$ has the greatest hardness and compressive strength of $55.274 \mathrm{HV}$ and $1.42 \mathrm{MPa}$, respectively which is due to the present of uniform porosity in the sample. It was also observed that although the deformation plateau region is the shortest, the optimized sample has interconnected and uniform pores.

The authors acknowledge the support provided by Universiti Teknologi PETRONAS for necessary support throughout the project.

\section{References}

1 V. K. Jeenager, V. Pancholi, and B. S. S. Daniel, Adv. Mater. Res., vol. 585, pp. 327331 (2012)

2 B. Bauer, S. Kralj, and M. Bušić, vol. 20, no. 6, pp. 1095-1102 (2013)

3 S. Talebi, M. Sadighi, M. M. Aghdam, and S. M. H. Mirbagheri, Mater. Today Commun., vol. 13, no. September, pp. 170-177 (2017)

4 Y. Wang, X. Ren, H. Hou, Y. Zhang, and W. Yan, vol. 275, pp. 344-350 (2015)

5 A. Uzun and M. Turker, Mater. Res., vol. 17, no. 2, pp. 311-315 (2014)

6 T. Geramipour and H. Oveisi, Trans. Nonferrous Met. Soc. China (English Ed., vol. 27, no. 7, pp. 1569-1579 (2017)

7 D. Lehmhus and J. Banhart, Mater. Sci. Eng. A, vol. 349, no. 1-2, pp. 98-110 (2003)

8 J. Banhart, Adv. Eng. Mater., vol. 15, no. 3, pp. 82-111 (2013)

9 N. Movahedi, S. M. H. Mirbagheri, and S. R. Hoseini, vol. 20, no. 4, pp. 757-763 (2014)

10 T. Neu, B. Pfretzschner, F. García-Moreno, and J. Banhart, Metals (Basel)., vol. 7, no. 9 , p. 323 (2017)

11 T. Miyoshi, M. Itoh, S. Akiyama, and A. Kitahara, Adv. Eng. Mater., vol. 2, no. 4, pp. 179-183 (2000)

12 S. Kumar, R. Pandey, and O. P. Pandey, Procedia Mater. Sci., vol. 5, no. December, pp. 891-897 (2014)

13 W. D. C. and . D. G. Rethwisch,. John Wiley \&Sons, Inc (2010)

14 X. Xia, H. Feng, X. Zhang, and W. Zhao, Mater. Des., vol. 51, pp. 797-802 (2013)

15 Y. H. Song, M. Tane, T. Ide, Y. Seimiya, B. Y. Hur, and H. Nakajima, Mater. Sci. Forum, vol. 658, pp. 189-192 (2010)

16 U. A. Atturan, S. Harsha, B. S. Murty, and S. Sankaran, Mater. Sci. Eng. A, vol. 684, no. September 2016, pp. 178-185 (2017)

17 V. K. Jeenager, V. Pancholi, and B. S. S. Daniel, Mater. Des., vol. 56, pp. 454-459, 2014.

18 H. Yu, Z. Guo, B. Li, G. Yao, H. Luo, and Y. Liu, Mater. Sci. Eng. A, vol. 454-455, pp. 542-546, Apr. 2007. 